\title{
Implementation of Electronic Services in The System of Population Social Protection
}

\author{
Anna Zastelo ${ }^{1}$, Tetiana Serha ${ }^{1}$, Vladislav Koval ${ }^{1}$, Yana Vikhliaieva $^{1}$, and Nataliya Shuberty ${ }^{1}$ \\ ${ }^{1}$ National University «Zaporizhzhya Polytechnic», 69063 Zaporizhzhya, Ukraine
}

\begin{abstract}
The study assesses the status and opportunities for the introduction of electronic social services in Ukraine on the example of Zaporizhzhya region. The peculiarities of providing and receiving e-social services based on the analysis of the main models of e-government and individual countries within the selected models: Anglo-American, Continental European and East Asian. The ambivalence in the perception of the population's readiness to receive electronic social services among experts and clients has been determined. The results of the comparative analysis revealed some statistically significant differences in determining the reasons for the slowdown in the process of implementing the provision of electronic social services. The main factors that will contribute to the development of electronic social services are highlighted.
\end{abstract}

\section{Introduction}

Today, Ukraine follows the practice of foreign countries, not only in political processes but also in governing the country. The development of Ukraine is also envisaged in the creation of e-government, in the development of the provision of electronic social services.

The purpose of the study is to assess the state and possibilities of introducing electronic social services in Ukraine (on the example of the Zaporizhzhia region).

The research objectives:

1) to determine the features of the experience of providing (receiving) electronic social services;

2) to determine the factors for optimizing the development of social services in the system of electronic services.

To study the features of the state and opportunities for the introduction of electronic social services in the Zaporizhzhia region, the following was carried out: 1) an expert survey among managers and employees of social services and social service institutions $(\mathrm{n}=100$, August 2020) 2) a mass sociological survey among clients of social services and social service institutions service $(\mathrm{n}=300$, Aug 2020). Characteristics of the sample of a mass sociological survey among social services clients and social service institutions $(\mathrm{n}=$ 300): 1) by gender: men - $30.3 \%$; women $-69.7 \%$; 2) by age: $15-30$ years old $-24.6 \%, 31-50$ years old $61.5 \%$, 51 years and older $-13.9 \%$; 3 ) by type of settlement. Zaporizhzhia - $40.2 \%$, regional center, countryside - 59.8\%. Characteristics of an expert survey sample among managers and employees of social services and social service institutions $(\mathrm{n}=100)$ : 1) professional work experience: up to 3 years $-23.4 \%$; from 3 to 10 years old $-46.8 \%$; from 10 years old -
$29.8 \%$; 2) by type of settlement, Zaporizhzhia - 57.4\%, regional center, rural area $-42.6 \%$.

\section{Results}

The development of the information society in Ukraine and the introduction of ICT in all spheres of public life create fundamentally new opportunities for social work. In the information society, work in the social sphere requires knowledge and skills of effective search, accumulation, processing, storage, presentation, transmission of data using computers and Internet networks. In the context of the introduction of egovernment in Ukraine and the process of public services' digitalization, the problem of technologies incorporation for the provision of electronic social services into the social work sphere is actualized.

During the restructuring of e-government in Ukraine, it is very important to study and borrow the best experience of foreign countries, which will help identify promising ways for the further development of e-government in Ukraine, and in particular the introduction of e-services provision to the population. Let us analyze the features of the main models of egovernment and individual countries within the framework of the selected models: Anglo-American, Continental European and East Asian.

Anglo-American e-government model.

The Anglo-American model is typical for countries such as the United States, Canada, Britain and Australia. Typical features of the Anglo-American model arise from the peculiarities of the territorialpolitical structure and traditions of statehood: a high level of independence of territorial administrations (states) in conjunction with a strong central government. The model is designed to create electronic 
government for countries with a large territory and fairly uniform Internet access.

The Anglo-American model, on the one hand, allows for a significant difference in the processes of local e-government, and on the other hand, it clearly standardizes the rules for the exchange of information "citizen-government" at the national level. The system of local government in the states is based on the administrative-territorial division, therefore, the schemes of self-government in different states are different [1].

An important component of the success of the Anglo-American e-government model implementation has become significant reforms of the entire structure of the state's work with information flows and the introduction of responsibility system for the government agencies informatization.

Electronic government in the United States began with the creation of the President of the United States website in 1993. The main purpose of which was to inform the country population about the activities of the Presidential Administration via the Internet. However, already in early 1994, a working group on egovernment was established, which included more than 80 representatives from 46 government agencies and bureaus. This group has developed an e-government strategy document aimed at modernizing government performance. This group concluded that the federal government can significantly improve the efficiency of serving its users in the coming period of up to 24 months, focusing on 23 high-priority, governmentwide initiatives. [2] These initiatives ensured the delivery of services to citizens in terms of minutes or hours, instead of days or weeks.

The main US government portal [3] was launched in 2000. It brings together many sites at the level of integration links, contains complete information about government resources, services and forms for citizens, business and government. Online services featured on the US government web portal are provided by redirecting to the appropriate sites. To solve the problems of integrating interdepartmental projects, the US government relies on the concept of federal corporate building. The main goal of the federal information technology architecture is to provide conditions for the interdepartmental development of processes, standards and information exchange [4]. Later the e-government law was adopted in the United States, (the E-Government Act of 2002), which was aimed at expanding access to information about the government, as well as providing information and services to citizens, employees, other agencies and legal entities [3].

Public discussions can serve as a striking example of wide public involvement in the e-government system. In the United States, the obligation to conduct discussions of draft regulatory acts is enshrined at the legislative level in the Law on Administrative Procedure [5], which, however, leaves it to the discretion of government institutions to determine the forms of communication with the public (usually a certain time is given to send comments on draft decisions).
A second potentially useful means of enhancing citizen participation in influencing policy-making is through electronic petitions (e-petitions). As a rule, the Internet is better suited for using this tool, thanks to which the public and interest groups can initiate a collective appeal, gather a group of its supporters who agree to support it with their signatures and send it to the appropriate government agency or to the government.

In a direct democracy, citizens' participation in the decision-making process is usually carried out by voting. E-voting is one of the techniques for improving and strengthening (quantitatively and qualitatively) public participation in the process of policy formation and decision-making at all levels of government: local, regional, national. This e-democracy tool aims to enhance the democratic and legitimate governance through the use of ICTs to directly determine the will of the voters.

Thus, the e-government model is determined by the structure and traditions of public administration in the United States. The path of the information society formation is determined by the general model of socioeconomic development, in which the functions of the state are reduced to a minimum, and the activities of individuals - to a maximum, therefore, the main priorities in the provision of electronic services are; firstly, the introduction of e-democracy tools (discussion, petitions, e-voting), and secondly, the interaction of the state with business and public associations, the sphere of social security and social services is covered to a lesser extent.

The UK e-government initiative is a fundamental element of the government's modernization program. E-government sets the strategic direction for public sector transformation by introducing business models that take advantage of the latest technology. Four principles of e-government in Great Britain: 1) compliance of public services with the needs of citizens; 2) ensuring greater accessibility of the state and its services; 3 ) the principle of social equality in access to public services; effective use of information [6].

The Continental European e-government model.

The Continental European e-government model operates in the countries of the European Union (EU). The Continental European e-government model was developed taking into account the fact that the European Union includes 28 countries with different languages, cultural and political traditions. At the level of an individual EU member state, the elements of egovernment can be very different both in terms of the technical platform use and in terms of the interaction organization between the state and the citizen (evoting, services to the government, payment of taxes and fines, etc.). At the same time, between the members of the European Union, for the development of the e-government system, the minimum necessary legal framework was agreed. It is expressed in the form of directives of the European Commission, all member states have implemented into national legislation.

At the level of the supranational structures of the European Union (the European Parliament, the 
European Commission, the European Court of Justice), the continental European model of e-government is due to the clear unification of interaction between supranational structures and intrastate structures of the member states of the Union. Also, according to this model, a citizen of any European Union state can, through the electronic government system, apply directly to the pan-European authorities in real time.

All EU countries have adopted laws on access to information. The requirements of the European Union for legislation governing e-government systems cover both technical aspects (digital signature, e-commerce) aimed at simplifying the creation of e-government systems, and ethical and political issues (distribution of government orders, access to information), define new responsibilities "Responsibilities state institutions for the protection of citizens' rights and organizations in the new context of the provision of public services by electronic means.

The continental European model of e-government is characterized by: the presence of supranational institutions, the recommendations of which are binding on all EU countries; a high degree of European countries integration is manifested in a single panEuropean information space; strict regulatory legislation in the information sphere. The management and activities of national governments and supranational structures in this model are due to the use of high technologies with a focus on the needs of citizens - users of information networks and systems. When it comes to building an e-state, the EU focuses on achieving social cohesion between member nations and the European community as a whole. The Information Society for Europeans is a means of preserving the diversity of Europe. For Europe, investments in information society technologies are, first of all, investments in people.

The path chosen by the countries of Europe differs from the American one. In 2000. the leaders of the European Union adopted the Lisbon Strategy [7] in order to make the EU a dynamic and competitive knowledge-based economy in the world. Information and communication technology has been a key component in achieving these goals. A special program "e-Europe" [8] was developed to realize the goals of the Lisbon ICT Strategy.

In the program "e-Europe" 2000-2002. there were three main goals: a cheaper, faster and safer Internet, investing in people's skills, and increasing Internet usage. Later, these goals were changed in the following EU programs for the implementation of e-government $[9,8]$ to provide public services online, a dynamic ecommerce environment, ubiquitous broadband access and secure information infrastructure [10]. Essential documents in this area are also "The Role of EGovernment for the Future of Europe" [11] and "EGovernment in Europe: the state of affairs" ("EGovernment in Europe: The State of Affairs "[12]), presented at the European conference in the city of Cernobbio (Italy).

The European Union has introduced a system of continuous monitoring of the characteristics of the following electronic services to citizens and businesses: 1) services to citizens: provision of public information and responses to inquiries; assistance in declaring taxes; job search through the employment service; provision of social assistance, payment of unemployment benefits, per child, reimbursement of medical expenses, tuition fees; issuance of personal documents (passport, driving license, car registration, filing applications for construction, informing the police (theft, etc.), providing access to public libraries (availability of catalogs, search tools), issuing birth and marriage certificates, accepting applications to higher education institutions, informing about a change in residence, services related to medicine (interactive consultations, requests for treatment in a specific place, the availability of services in a hospital), etc. 2) services to business are carried out in such areas as social contributions from wages workers' wages; corporate taxes and declarations; value added tax; registration of a new legal entity; reporting statistics; Customs declaration; obtaining permits related to environmental protection; government procurement and the like.

As part of the Europe2020 strategy, one of its seven flagship initiatives was adopted - the Digital Agenda for Europe [13], which is an action plan aimed at achieving a dual goals: ensuring the global competitiveness of the European Union through the development and implementation of ICT, as well as the spread of digital technologies in all spheres and layers of the European society.

Today, the "Digital Agenda for Europe" is the main current project document for the development of the information sphere of the European Union, which identifies 101 events within the "seven pillars" around which it is planned to reboot the economy of the European Union in order to get the most out of digital technologies for citizens and businesses. These key areas are [13]: creation of a single digital market; achieving interoperability (interoperability) of software and content, optimization of relevant standards; increasing user confidence and safety; development of high-speed internet; development of scientific research and innovation; spreading digital literacy and IT skills; IT for solving social problems.

Consider the introduction and development of egovernment using the example of France.

The formation of the information society in France is characterized by a number of profound transformations. Among the main stages of France egovernment introduction, one can single out the stage of strategic planning and the stage of direct implementation. During the first stage, which began in January 1998, a general strategy for the formation of an "information society" in the country and the construction of "electronic government" structures was agreed and approved by all government bodies. The goal of this program was to accelerate the formation of the information society and make it accessible to everyone. The program took into account: the real possibilities that France has for building a nationwide and publicly accessible system of information services; positive and negative experience of the world, accumulated in the process of creating such systems; 
basic requirements and parameters of the plan "Electronic Europe 2002".

The stages of the PAGSI plan (government action plan for the creation of an electronic society) included: opening by the end of 2000 public access to government services and documents; organization of high-speed Internet access; support for training, research; accelerating the development of information and communication technologies (ICT); each ministry was given the task of developing projects of websites containing information about their activities and the services they provide.

The priority tasks of the program included the development of the following key directions of the country informatization: 1) in the field of education: creation of a specialized educational network in the national Internet zone; 2) in the field of promoting culture and art in France: electronic copying of works of art and other elements of cultural heritage, the creation of virtual museums and libraries; 3) in the activities of public administration bodies: information technology (IT) modernization of public services in order to provide enterprises and citizens with access to their information resources and provide an opportunity to interact with them using the Internet; 4) in conducting scientific research and introducing innovations: supporting the development of new technologies and industrial innovations in order to develop national science, industry and the economy in general; - in matters of jurisprudence and law: solving the problems of legislative regulation of the activities of the state, business and citizens on the Internet; 6) in the e-commerce sector: promoting the development of legitimate commercial transactions on the Internet [14].

The second stage of e-government development in France was aimed at the timely and almost complete implementation by 2002 of all the main provisions of the PAGSI program, which allowed the new French government, headed by Prime Minister Jean-Pierre Raffarin, to announce the end of the first building stage an information society in the country and the transition to the next, second stage of e-government, which included: 1) creation, on the basis of the existing program, a system of "complete electronic" state administration, advanced by world standards, due to the introduction of a highly efficient mechanism of the State-Consumer (administration-to-consumer), which will ensure the possibility of providing citizens and enterprises with all public services via the Internet; 2) the transition of the entire state administrative apparatus to the use of absolutely paperless technologies and a fully computerized mode of operation, due to which budget savings, according to the calculations of the Ministry of Finance specialists, amount to at least 7 billion euros per year [14].

In 2003, the French Ministry of e-Governance and Administrative Reforms developed and issued a strategic plan ADELE (ADministration ELEctronique). It includes strategic and tactical action plans that should be reviewed annually and updated accordingly. The $A D E L E$ strategic plan has a detailed structure for the development of the e-government of France. This concept is based on the following principles: government should focus on citizens, not bureaucracy; effectiveness; innovativeness; transparency and control by citizens; confidentiality; compatibility of services and information systems [15]. The ADELE main task is to implement e-administration through achieving a high level of accessibility and ensuring interactivity, allowing users to perform all administrative procedures and services online.

Let consider the e-services provided to businesses and citizens in France as a result of France egovernment introduction. The assessment methodology and the level of online service provision are determined by the EU Council, according to which the following information is provided. The main public services for citizens are: income taxes (makes it possible to submit a declaration, report, pay taxes) job search by the Employment Agency (makes it possible to register at the labor exchange); social insurance (makes it possible to receive social assistance) personal documents (makes it possible to issue a passport or driver's license); car registration (makes it possible to register your car); building permit; declaration to the police (makes it possible to file a statement with the police) public libraries (makes it possible to find a book in the online library) certificates of birth, marriage (makes it possible to order a marriage certificate or the birth of a child); admission to the University; change of residence address; health-related services (makes it possible to make an appointment with a doctor), etc. [14].

France's e-government strategic program is built on the following fundamental principles: 1) continuous assessment of user needs. Creation of advisory centers throughout the country with the aim of increasing popularity, establishing a dialogue, presenting a new program (counseling is carried out by an experienced group of people); 2) ensuring the availability of eservices for every citizen. Use of service terminals especially in rural areas, simplification of administrative procedures; 3) the establishment of trust between the state and citizens. Confidentiality and control of personal data by users 4) provision of an effective and full range of administrative and social services, keeping government spending under control, increasing the provision of new services without increasing costs.

The East Asian e-government model.

The East Asian e-government model is typical for countries such as: Singapore, Japan, South Korea, Taiwan. The Eastern model is based on a specific management style, an Asian type of corporate culture and a multilayered system of public administration, organized according to the principle of a hierarchical pyramid. Its representatives seek to introduce an alternative Western approach, which is based primarily on the assertion of their own value orientations in industrialization, informatization and social development. It is based on cooperation between the state and the market, an attempt to establish a connection between the cultural values inherent in the supporters of Confucianism, accompanied by social changes. The model is good for monocultural states, even large in terms of territory, with a high population 
density and generally accessible high-speed Internet access.

Within the Eastern model, Japan, "Asian tigers" and China are distinguished. The concept of "Japanese economic miracle" is textbook. The country's successes in the development of the information society as a whole coincide with the successes of the United States in this area. One of the most important factors in their achievement is significant expenditures on research and development, the high priority of ICT in solving the problems of the country's socio-economic development. Overall, Japan's e-government program pursued two goals: to provide user-centered management services and to implement public administration. Real progress has been made in empowering individuals and businesses to apply and register for virtually all national administrative procedures. So, since 2005, $96 \%$ of national administrative procedures are available online, for example, such as tax registration and request to the social insurance system [16].

The information development of the "Asian tigers" (South Korea, Taiwan, Singapore and Hong Kong) is based on the so-called model of economic cooperation between the state and the market - public-private partnership. The success of these countries is based, in particular, on state intervention in decision-making in the field of large private investments and on the active participation of the state in the national information infrastructure creation. The problems of information development, which the governments of these countries are focusing on, are the constantly growing competition in the production and implementation of the latest ICTs, the associated potential loss of a certain market segment or jobs, as well as the problem of ensuring equal access to information resources.

In the concept of electronic government in South Korea, the Government for Citizens (G4C) program is being implemented, which is aimed at simplifying the procedures for interaction between government agencies and citizens of the country and legal entities. The program is focused on minimizing direct contacts between officials and citizens of the country and business entities. Currently, the government offers a significant number of online integration services as a one-stop-shop.

So, for more than two decades since the practical implementation of e-government technologies in various countries, significant experience has been accumulated, as a result of which resources and time have been saved and a high-quality assessment has been provided for the results of a comprehensive assessment of the e-government development. "United Nations E-Government Survey 2018 In Support Of Sustainable Development" from the United Nations, in 2018 Ukraine took 82nd place among 193 countries that participated in the assessment [17]. Compared to the 2016 rating "United Nations E-Government Survey 2016 E-Government For The Future We Want" (held every two years) - Ukraine has decreased in the 2018 rating by 20 positions, which indicates certain systemic problems in many areas of the implementation of electronic management in Ukraine (Fig. 1).
The use of successful practices of foreign countries is becoming a necessary factor in achieving the goals of e-government, preventing possible problems of informatization of public authorities and the development of the information society.

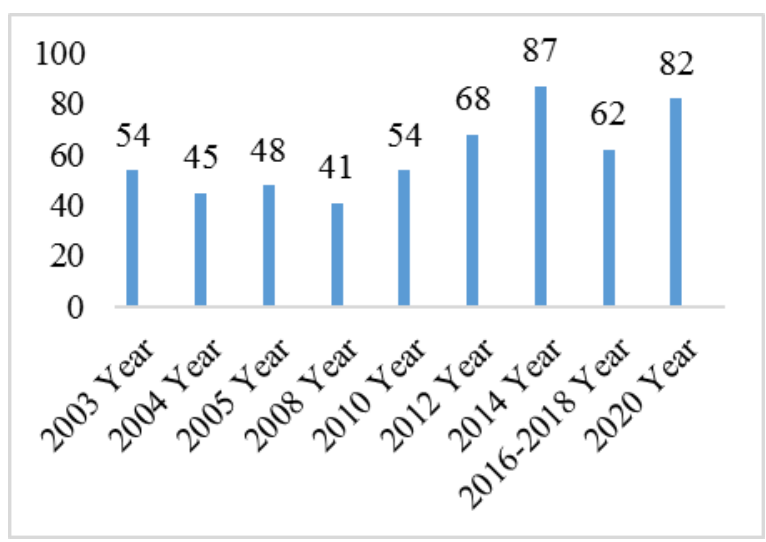

Fig. 1. Dynamics of Ukraine's readiness for e-government according to various UN ratings "E-Government Survey" for 2003-2020

The development of e-governance in Ukraine is primarily associated with the creation of a regulatory framework for the development of the information society in the context of European integration processes. Ukrainian researchers identify several stages in the implementation of e-government in Ukraine.

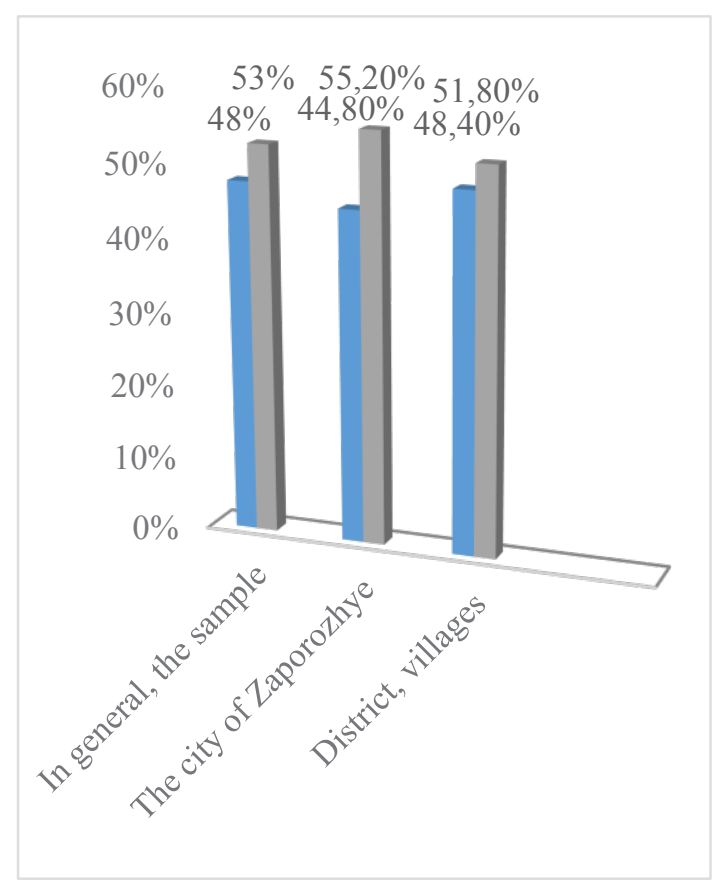

Fig. 2. The experience of receiving electronic social services among clients

Experience in providing (receiving) electronic social services. The rapid development of the modern information use and communication technologies and the Internet already allows the use of various forms of providing and receiving electronic social services, is spreading due to the state policy of public services digitalization ("the state in a smartphone"), among which the electronic registration of social services is in special demand. benefits, allowances, pensions, etc., therefore, the indicators of the study indicate that 
almost half of the respondents have already had such an experience (Fig. 2-3).

$59 \%$ of the surveyed social workers noted that they already have experience in providing electronic social services, and there were more of them in the regional centers of the Zaporizhzhia region than in the regional center $(67 \%$ and $43 \%$, respectively), but these indicators are determined by those forms of electronic the tools that they use in their professional activities (Fig. 3).

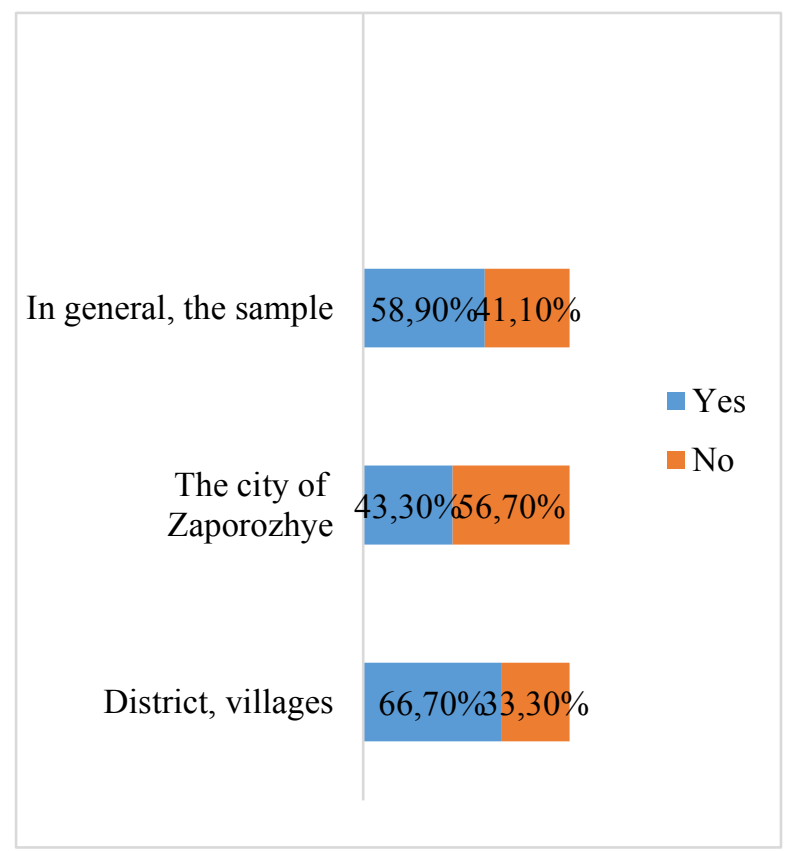

Fig. 3. The experience in providing electronic social services among experts

Among the electronic tools that social workers use in their professional activities, the most common are: Google services (60\%), electronic inquiries and inquiries $(45 \%)$, the website of a social service institution (42\%) and social networks (40\%). Tools that directly enable open communication in the process of providing social services (communication online services) are used by only $30 \%$ of social lawyers (more of them in Zaporizhzhia city).

So, it can be noted that at this stage of development of the provision of electronic social services, the tools that are used by ordinary Internet users (Google services and social networks) and the opportunities provided by the format of the site of the social service institution, among which electronic requests and requests dominate to receive social services (which is more common in district centers of social services and social services).

If the identification of the experience level in receiving and providing electronic services determines the real state of modern information application and communication technologies in social work and social services (in this case, at the regional level), then the indicator that determines the possibility of their use is the assessment of the readiness of both suppliers and recipients of development social service systems using Internet technologies and remote communication. In this aspect, an expressive indicator is the assessment of the population readiness to receive electronic social services from the point of view of both the recipients themselves and from the position of social services providers.

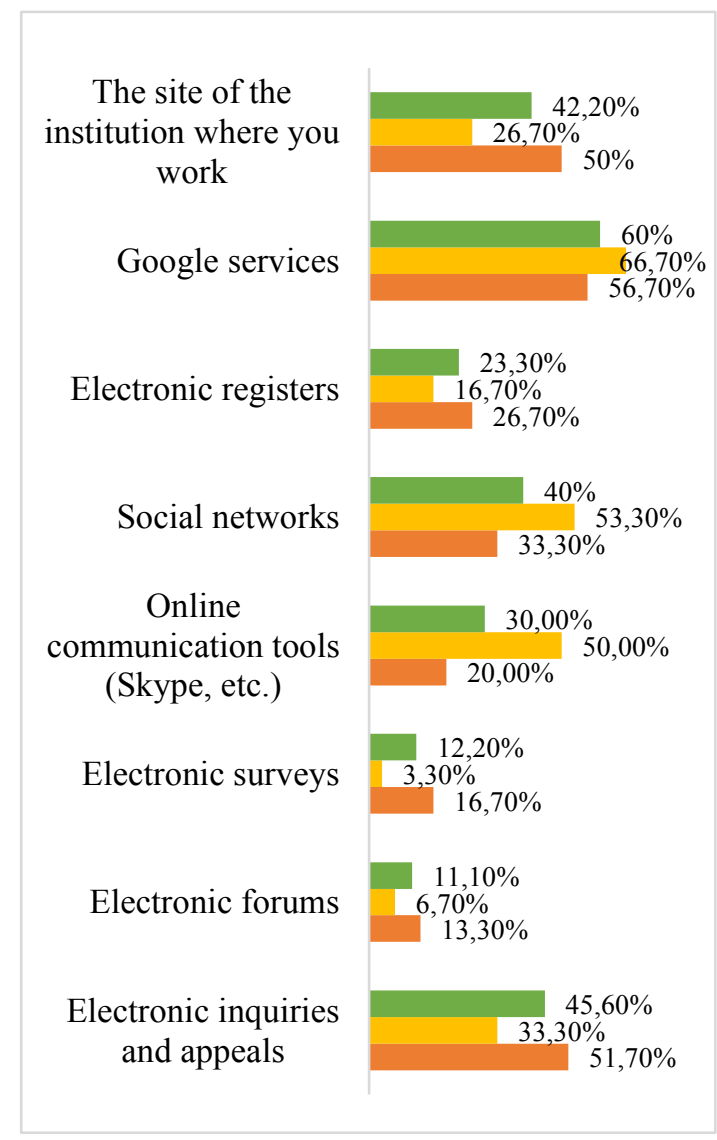

Fig. 4. The experience in using electronic tools in professional activities among experts (several options could be chosen)

According to the results of the study, a positive assessment of the population readiness to receive electronic social services is $32 \%$ of the interviewed experts and clients, that is, the points of view of recipients and social services providers in this matter coincide; negative assessment of readiness is also almost the same $(40 \%$ among interviewed clients and $36 \%$ among experts). $30 \%$ of the respondents have defined their position and possibly represent a group of social service entities with a sufficient level of awareness and awareness of the possibilities of using egovernment tools in the social service system.

According to the place of residence and work and experienced research results have some statistical discrepancies. So, among the experts representing social services and social service institutions in the regional center, $20 \%$ of respondents gave a positive assessment of the population readiness, in district institutions - $38 \%$. Distribution by negative assessment of readiness: Zaporizhzhia - $37 \%$ and regional centers $37 \%$.

On the other hand, the population itself (as clients of social services and social service institutions) evaluates their own readiness to receive electronic social services differently (Fig. 3.10). Thus, residents of Zaporizhzhia are generally ready for the 
introduction of electronic social services $(41 \%$ of respondents gave a positive assessment and $34 \%$ - a negative one), and clients living in regional centers and rural areas believe that the population is not ready for digital transformation in the social service ( $42 \%$ gave a negative rating and $29 \%$ gave a positive rating).

So, we can observe an ambivalence in the perception of the population's readiness to receive electronic social services among experts and clients: social workers of regional centers and clients of social institutions from the regional center are optimistic, and social workers of Zaporizhzhia and clients of social institutions from regional centers are negative. This dissonance of ideas, in our opinion, reflects the following trends: first, the optimistic attitude of social workers in the periphery, associated with the ability to simplify the provision of social services in remote settlements and villages, thereby reducing the burden; and secondly, the pessimistic attitudes of the population of the districts of the Zaporizhzhya region, which is represented by the older age category, do not have both subjective motivation for remote communication and objective conditions for receiving electronic services (lack of the Internet, technical support, ICT skills, etc.).

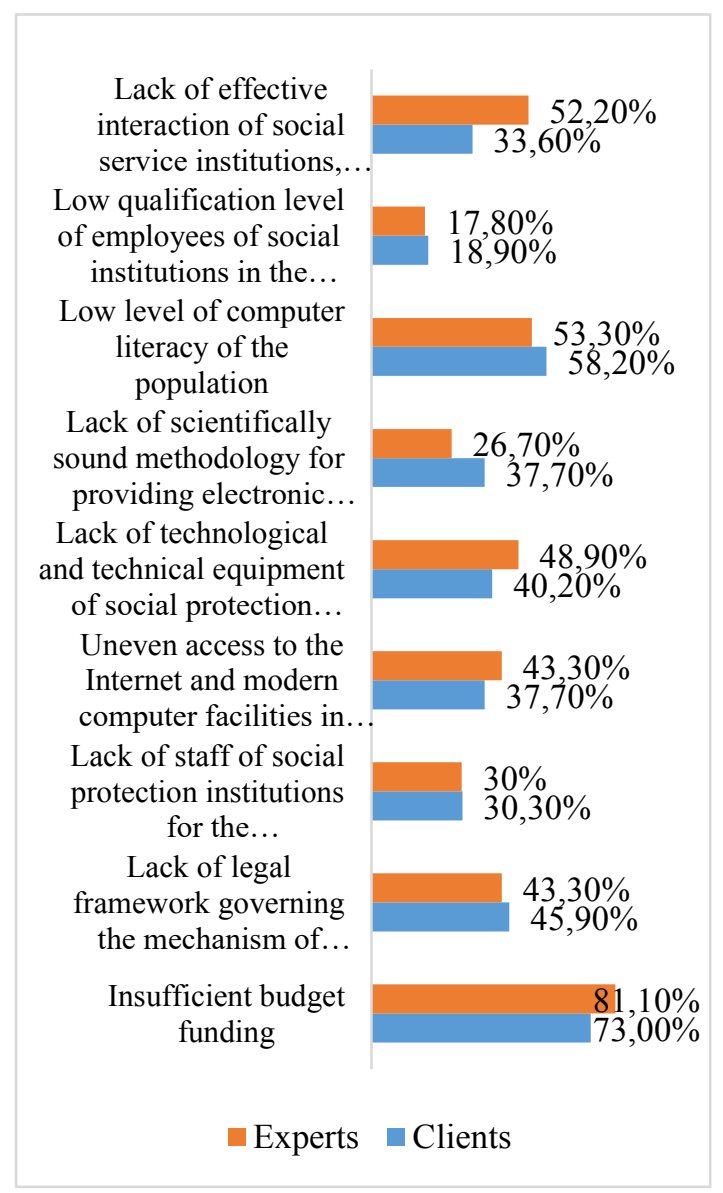

Fig. 5. The main reasons for the slowdown in the implementation of the electronic social services provision in Ukraine

Factors for optimizing the social services development in the system of electronic services (Fig. $5)$.
A comparative analysis of experts and clients survey results found some revealed some statistically significant differences in determining the reasons for the slowdown in the implementation of the electronic social services provision. So, for experts, such factors are: insufficient budget funding, low level of computer literacy, lack of well-established government-privatepublic interaction in the development of the electronic social services provision in the region, low level of technical support and uneven access to the Internet, and there are more of these among social workers of social service institutions in the Zaporizhzhya city.



Fig. 6. The main reasons for the slowdown in the implementation of the electronic social services provision in Ukraine (experts)

For clients of social services, the main factors that will contribute to the development of the electronic social services provision are: an increase in budgetary financing of the social service system, computer, lack of a legislative framework and scientific justification for the implementation of a social services system for 
the population in the context of e-government development.

According to the social services' interviewed clients' age categories, can single out the actual directions of optimizing the process of introducing electronic social services. For the age category from 15 to 30 years old, such factors are: technological and technical support and computer; from 31 to 50 years equal access to the Internet, a high level of computer literacy, substantiation of the methodology for the provision of electronic social services; for the population of 50 years and older - sufficient funding and material and technical provision of social service institutions, advanced training of social workers.

\section{Conclusions}

So, based on the results of expert and mass sociological surveys, the following conclusions can be drawn:

- firstly, half of the respondents (both clients of social services and social workers) already have experience in social services in electronic form, to a greater extent associated with the general trend of electronic government development in Ukraine through government Internet portals;

- secondly, at this stage of development of the electronic social services provision, most of all are used tools that are available to all Internet users, and those opportunities provided by the format of the social service institution site, among which electronic requests and requests for social services dominate;

- thirdly, a positive assessment of the population readiness to receive electronic social services is $32 \%$ of the surveyed experts and clients, that is, the points of view of recipients and providers of social services in this matter coincide;

- fourth, the main factors of slowing down the provision of electronic social services development in the region are: insufficient budget funding, low level of computer literacy, lack of well-established publicprivate-public interaction in the development of the electronic social services provision in the region, low level of technical support and unevenness access to the Internet.

\section{References}

1. M.S. Mikhrovska, Legal scientific electronic journal, 7, 272-275 (2020)

2. O. Onufriienko, Public administration and local self-government, 1(40), 21-33 (2019)

3. The U.S.A. Government's Official Web Portal. http://www.usa.gov

4. V.V. Yvanov, A.N. Korobova, Gosudarstvennoe $i$ municipal'noe upravlenie s ispol'zovaniem informacionnyh tehnologij (State and municipal management with the use of information technology). (INFRA-M, Moscow, 2018)

5. R. Lindner, G. Aichholzer, European EDemocracy in Practice (2019) https://link.springer.com/chapter/10.1007/978-3030-27184-8_2
6. V.S. Politanskyi, Scientific Bulletin of Public and Private Law, 2, 29-35 (2018)

7. Lisbon Strategy http://cordis.europa.eu/programme/rcn/843_en.htm 1

8. A.O. Serenok, Pressing problems of public administration, 2(50) (2016)

9. Yu.O. Kovalenko, Reporter of the priazovskyi state technical university, 35, 271-280 (2018)

10. B Warf, IJEPR, 7(4), 61-77 (2018)

11. J.M. Sánchez-Torres, I. Miles, European Journal of Futures Research, 5 (2017)

12. eGovernment in the European Union 2016 https://joinup.ec.europa.eu/sites/default/files/inline

files/eGovernment_Factsheet_European_Union_Ju ne 2016 v 7 04.p̄df

13. I. Bertschek, J. Ohnemus, ZEW policy brief, 2 (2016)

14. E-Gouvernement: le digital au service du développement économique et du bien-être de vos citoyens http://sofrecomproduction.s3.amazonaws.com/2017/03/15/11/18/ 06/751/Livre_blanc.pdf

15. Features of e-government, http://www.egovinterop.net/Res/9/eGovInterop $\% 2$ 006\%20\%20Programme\%20final.pdf

16. B. Warf, e-Government in Asia:Origins, Politics, Impacts, Geographies (Chandos Publishing, 2016)

17. UN study: e-government. The use of egovernment to build a sustainable and flexible society (2018),

https://publicadministration.un.org/egovkb/Portals/ egovkb/Documents/un/2018-Survey/EGovernment\%20Survey\%202018_Russian.pdf 